\title{
The Canadian Muslim Network Tribute to Civil Liberties in Canada: In Honour of Maher Arar and Monia Mazigh
}

\author{
Statement Delivered on behalf of \\ the Canadian Muslim Network by \\ Dr Tyseer Aboulnast, O.ONT, \\ Parliament Hill, Feb 14, 2007
}

The Honourable Mr Stephane Dion, Leader of the Liberal party of Canada, M. Gilles Duceppe, chef de la Parti Bloc Quebecois, The Honourable Jack Layton, Leader of the NDP party, senators and parliamentarians, Mr. Arar and Dr. Mazigh, honored guests, or in likely more appropriate terms for this event, friends and fellow Canadians:

Assalamu Alaykum. May you all be in Peace.

Let me welcome you all with the greeting of Islam on behalf of the Canadian Muslim network; a network of Muslim organizations across Canada from BC to Alberta all the way to Ontario, Quebec and the Maritimes. The network was put in place to create an environment of collaboration and communication between Muslim organizations on issues of interest to Muslim Canadians nationally as well as to enhance communication and collaboration between Canadians of Muslim faith with Canadians of all other faiths.

The list of names of the organizations in the network is at the back of your program (attached here as appendix), and I invite you to look at it in detail to appreciate the breadth of representation here tonight. This initiative is also supported by a multitude of other organizations that are also listed at the back.

As you may expect civil liberties is high on our agenda. The Canadian Muslim Network is proud to have organized this incredible event to pay tribute to our cherished civil liberties in Canada, to recognize the massive effort that many in this room exerted to ensure we restore our civil liberties and protect them for the future of our children and to remind ourselves that while we have reasons to celebrate our recent successes, the road ahead is still long.

We are here today to pay tribute to civil liberties in Canada. Canada is a country that was never defined by the colour of the skin of its people or their religion, rather Canada was always a country defined by its values. Canada 
is a country that took enormous pride in its charter of rights and took its charter of rights very seriously.

All this started to change after September 11. An environment of fear descended on Canadians of all faiths, be it elected politicians or average people on the street. While we were all afraid of threats from the outside, Muslim Canadians, Arab Canadians and anyone looking like they might be Muslim or Arab had to cope with threats from the inside as well.

Despite the fact that we seemed initially to consciously recognize that in Canada we do things differently, things gradually changed. Despite starting out with a statement from the Prime Minister at the time:

Our actions will be ruled by resolve, not by fear. If laws need to be changed, they will be. If security has to be increased to protect Canadians, it will be. We will remain vigilant. But we will not give in to the temptation, in a rush to increase security, to undermine values that we cherish and which have made Canada a beacon of hope, freedom and tolerance in the world.

Despite this very Canadian position, shortly after September 11, we quickly found ourselves in a country were people can be jailed without knowing the charges against them.

A country where we are complicit in torture and where reputable institutions not only failed in protecting Canadians rather prolonged their torture and later attempted to dismiss the seriousness of the role they played.

A country where people may soon find themselves inexplicably on a list that restricts their basic right to simply travel within their own country, not knowing why they got on the list or how they can get off the list.

Despite the grim reality painted by this picture, this is still Canada.

And precisely because it is Canada, we found ourselves in a country where individuals ranging from elected politicians from all parties, to lawyers, journalists, human rights activists and most importantly regular average Canadians rallying behind Monia Mazigh's relentless efforts to bring the case of Maher Arar to the attention of the public and later rallying around Maher himself. Once the Canadian public was aware of the facts of the case, we quickly realized the reality that this erosion of the rights of one Canadian is nothing short of a gigantic step towards the erosion of civil liberties as we know it in Canada. Once Canadians saw what was happening, the spirit of the true North strong and free came out in full force.

Precisely because this is Canada, enormous pressure was mounted on the government of the time to establish the committee of inquiry to find out the truth. Precisely because this is Canada, we are blessed with a fiercely independent court system and we are blessed with Justice [Dennis R.] 
O’Connor. After heroic efforts by Monia, Maher and the people we will recognize tonight, it came down to one man, to his integrity, courage and dedication to the protection of true laws of this country and our rights under these laws. It came down to one man, Justice O'Connor to finally press the button turning this huge ship back towards what has always made us the dignified nation that was respected, envied and looked up to by people around the world ... again not because of its power but because of its values.

The people in this room who we are honouring tonight are representatives of the army of Canadians that stood by Maher Arar and Monia Mazigh, on principle, to defend their rights knowing that this was a defense of all our rights. These are the ones that set the stage to give Justice O'Connor the platform to render his recommendations that we see as a chart for putting Canada back on its true path in this world. Understandably, Justice O'Connor cannot participate in this event but on behalf of the Canadian Muslim Network and I believe on behalf of everyone in this room and everyone in Canada, we say to him: Thank you for upholding the integrity of the Canadian legal system and standing up for the rights of all Canadians.

Again, because this is Canada, once the report was released, there was no turning back. Opposition parties would not drop the issue on principle and the whole parliament did the honorable thing and apologized to Maher and Monia. Because this is Canada, the Prime Minister of Canada, on behalf of the government of Canada, apologized to Maher and Monia taking a significant first step towards rebuilding what we lost in the aftermath of September 11.

Precisely because this is Canada, Canadians, of all faiths and backgrounds, are hoping that responsible acts by our politicians of all parties in the last few months are indeed a step towards restoring Canada's dignity amongst the nations of the world through restoring the dignity of individual Canadians and residents of Canada.

While the efforts of tonight's awardees, Justice O'Connor report and the response of our elected officials did go a long way towards erasing a shameful cloud on Canada's record as a nation long upheld as a model for the world, there is a lot more work that has still to be done for us to truly be worthy of this great country of ours.

We have to remain vigilant.

Three other Muslim Canadian men: Ahmad El Maati, Abdullah Almalki and Muayyed Nureddin await the truth in their cases. We must keep the pressure up till we know not just what happened but how it was ever allowed to happen.

Both Justice O'Connor reports, specially the second report calling for oversight by parliament must be implemented, and implemented in its true 
spirit. The parliament of Canada must exercise its responsibility over our national security institutions and ensure there is accountability to the public about their actions. The choice of the leadership of RCMP is critical and must reflect an understanding of the true meaning of accountability to Canadians.

We must remain vigilant and make sure the countries of the world, friends and foes alike, treat the Canadian passport with the respect that is due to it. We must make sure the countries of the world friends and foes alike know that Canada does not trample on the rights and civil liberties of its people and will not tolerate other countries trampling the rights and civil liberties of Canadians.

We must remain vigilant.

Three other Muslim men are held in prison for years not knowing the full evidence against them. Mohammad Mahjoub, Mahmoud Jaballah and Hassan Almrei are on hunger strike for 71-82 days with nothing being done to address the issues they raise about the conditions of their imprisonment. It is utterly unacceptable that in Canada, there would be people detained outside the Jurisdiction of the Office of the Correctional Investigator, the Ombudsman that the Canadian system chose to put in place to ensure the integrity of the jail system in Canada.

We must remain vigilant and ensure that the anti terrorism act is properly reviewed after the recent court decisions throwing out parts of its definition as unconstitutional.

September 11 did not happen because of a failure of the criminal code that is being addressed by the anti-terrorism act. The question must be seriously asked if indeed we do need anything more than what the current criminal code provides. We must ensure that our laws, passed in haste in the climate of fear following Sept. 11 do not provide a legal pretext to target any segment of our society.

We must remain extra vigilant.

We must ensure that Canadians currently imprisoned under the antiterrorism act are accorded the full protection of the law, that they are presumed innocent till proven guilty, they are made aware of all the evidence against them and given the opportunity to defend themselves. In short, that they are accorded the full rights that all Canadians are accorded irrespective of the gravity of the charges against them.

Tonight on the day usually reserved for those we truly care for and love, we have chosen to gather here tonight to celebrate our love for Canada and what Canada stands for in civil liberties. Friends, let us never forget that nations are not judged by the laws they write up and lock up in libraries, nations are judged by how they act at times when their dedication to these 
laws are truly tested. Every country that has chosen to sacrifice the liberties of its citizens and hold them in shackles has done that out of belief that this is necessary for its security. We, Canadians, know better. We know that security without liberty is simply imprisonment. Nothing is more secure than a maximum security prison. We deserve better. We cannot let Canada turn into a maximum security prison by imprisoning one Canadian without the presumption of innocence till proven guilty and without the full opportunity to defend themselves.

Indeed, security without liberty is imprisonment. Today, as we celebrate the hard work of many dedicated Canadians from all walks of life, including several elected officials from all parties, as we celebrate the hope that was restored in all of us by the actions of our court system, as we celebrate the recent responsible act of acknowledgment of the government of the grave miscarriage of justice in the case of Maher Arar ... as we celebrate, we call on our elected officials, over five years after the fateful events of September 11, to lead Canada back to its rightful position as the light unto the nations when it comes to civil liberties, social harmony and equal respect of all its citizens.

Benjamin Franklin once said: People who are willing to give up freedom for the sake of short term security, deserve neither freedom nor security.

We certainly deserve both of our liberties and our security. We must work together to ensure that we do not sacrifice one for the other and as Roosevelt said it so eloquently, lose the right to either one.

And to those wonderful people we are honouring tonight, to Maher and Monia and all the others about whom we will talk later; I recall what Martin Luther King said years ago: "We lose a part of our lives when we are silent about things that matter." Thanks to you and to your choosing to speak up about things that matter, and to speak loud enough to be heard above the calls for fear and paranoia, you have restored a piece of Canada's life.

Our freedoms and rights as Canadians matter. Our security against internal threats of segregation and social disharmony matters.

Indeed, we are grateful that you were not silent about things that matter.

Indeed, we pray that we will never again be silent about things that matter.

I thank you and leave you with the greeting of Islam.

Assalamu alaykum. 